\title{
“... to grasp the native's point of view ..." - A Plea for a Holistic Documentation of the Trobriand Islanders' Language, Culture and Cognition
}

\author{
Gunter Senft \\ Max Planck Institute for Psycholinguistics \\ Nijmegen, The Netherlands
}

\begin{abstract}
In his famous introduction to his monograph "Argonauts of the Western Pacific" Bronislaw Malinowski (1922: 24f.) points out that a "collection of ethnographic statements, characteristic narratives, typical utterances, items of folk-lore and magical formulae has to be given as a corpus inscriptionum, as documents of native mentality". This is one of the prerequisites to "grasp the native's point of view, his relation to life, to realize his vision of his world". Malinowski managed to document a "Corpus Inscriptionum Agriculturae Quriviniensis" in his second volume of "Coral Gardens and their Magic" (1935 Vol II: 79-342). But he himself did not manage to come up with a holistic corpus inscriptionum for the Trobriand Islanders. One of the main aims I have been pursuing in my research on the Trobriand Islanders' language, culture, and cognition has been to fill this ethnolinguistic niche. In this essay, I report what I had to do to carry out this complex and ambitious project, what forms and kinds of linguistic and cultural competence I had to acquire, and how I planned my data collection during 16 long- and short-term field trips to the Trobriand Islands between 1982 and 2012. The paper ends with a critical assessment of my Trobriand endeavor.
\end{abstract}

Keywords: Trobriand Islands, Kilivila, language documentation, learning the local language as a prerequisite for field research, common ground

\section{For Citation:}

Senft, Gunter. 2020. “... to grasp the native's point of view ...” - A plea for a holistic documentation of the Trobriand islanders' language, culture and cognition. Russian Journal of Linguistics 24 (1). 7-30. DOI: 10.22363/2687-0088-2020-24-1-7-30. 
Научная статья

\title{
«...как понять туземца...»- Необходимость целостного описания языка, культуры и менталитета тробрианцев
}

\author{
Гюнтер Сенфт \\ Институт психолингвистики Макса Планка \\ Неймеген, Нидерланды
}

\begin{abstract}
Аннотация
В знаменитом вступлении к своей монографии «Аргонавты западной части Тихого океана» (Argonauts of the Western Pacific) Бронислав Малиновский (1922: 24f.) отмечает, что «собрание этнографических описаний, характерных нарративов, типичных высказываний, элементов фольклора и магических заклинаний должно быть представлено в виде corpus inscriptionum как собрания свидетельств туземного менталитета». Это одно из условий «понимания точки зрения туземцев, их отношения к жизни, их мировосприятия». Малиновскому удалось создать “Corpus Inscriptionum Agriculturae Quriviniensis" во втором томе своего труда «Коралловые сады и их магия» (Coral Gardens and their Magic, 1935 Vol II: 79-342). Но он не смог представить холистический corpus inscriptionum тробрианцев. В ходе исследования языка, культуры и способов когниции тробрианцев я стремился заполнить эту этнолингвистическую нишу. В данной статье я рассказываю о том, как осуществлялся этот сложный и амбициозный проект, какими видами языковой и культурной компетенции мне пришлось овладеть и каким образом я планировал процесс сбора данных в течение 16 длительных и кратковременных полевых экспедиций на Тробрианские острова в 1982-2012 гг. В заключение статьи дается критический анализ моего Тробрианского проекта.
\end{abstract}

Ключевые слова: Тробрианские острова, Киливила, языковая документация, изучение местного языка как условие проведения полевого исследования, взаимопонимание

\section{Для цитирования:}

Senft, Gunter. 2020. “... to grasp the native's point of view ..." - A plea for a holistic documentation of the Trobriand islanders' language, culture and cognition. Russian Journal of Linguistics 24 (1). 7-30. DOI: 10.22363/2687-0088-2020-24-1-7-30.

\section{Introduction ${ }^{1}$}

In 1981 Irenäus Eibl-Eibesfeldt — the head of the Human Ethology Unit at the Max Planck Institute for Behavioral Physiology in Seewiesen - offered me a postdoc position as the linguist in his interdisciplinary project on "Ritual Communication on the Trobriand Islands". Our project was funded by the Max Planck Society and the German Research Society (DFG). In July 1982 I arrived in Papua New Guinea and a few days later I first set foot on the beach of the village

1 This paper was presented at the panel "Emancipatory Pragmatics: Probing language usage in diverse contexts" organized by Scott Saft, Sachiko Ide and Yoko Fujie at the 16th International Pragmatics Conference at the Hong Kong Polytechnic University, 9-14 June 2019 and as an invited plenary talk at the PASE conference in Poznan, 27-28 June 2019. I thank Sachiko Ide and Yoko Fujie for a grant which enabled me to participate in the IPrA conference in Hong Kong. I also would like to thank my audiences for helpful comments. 
Tauwema, my place of residence during my field research on Kaile'una Island, the second largest island of the Trobriand archipelago. Together with an anthropologist, the PhD student Ingrid Bell-Krannhals, I was supposed to do field research there from July 1982 till November 1983 - with a break of 6 weeks between the years. In 1983 my wife stayed with me in Tauwema for the whole year. In the years to come these first two fieldtrips were followed by 14 more short- and long-term periods of field research in Tauwema up till 2012. One of these field trips (in 1989) was financed again by the German Research Society in cooperation with the MPI in Seewiesen; during this field trip my wife and our then 2 and 4 year old children accompanied me. The other field trips - which I did on my own - were funded by the Max Planck Institute for Psycholinguistics in Nijmegen. In 1991 I left the Institute in Seewiesen and accepted a position in Stephen Levinson's Cognitive Anthropology Research Group (which became the Department of Language and Cognition in 1995) at the Max Planck Institute for Psycholinguistics. I kept this position until my retirement as extraordinary Professor of General Linguistics and Senior Investigator in February 2018. ${ }^{2}$

But back to the beginnings: My field research in 1982/83 was supposed to document as many forms of ritual communication as possible in Kilivila, the Austronesian language of the Trobriand Islanders, and to answer the research question "How can we refine the definition of ritual communication and improve theories that deal with this fascinating concept on the basis of empirical speech data?" Thus, from the very beginning my research on the Trobriand Islands had a somewhat "holistic" touch. When it became clear that I would have the unique opportunity to continue my research on the Trobriand Islands until the end of my career - though with different focal points in my research on the interface of language, culture and cognition - I immediately decided to do my very best to provide the corpus inscriptionum for Kilivila Bronislaw Malinowski so emphatically asked for in the famous introduction to his monograph "Argonauts of the Western Pacific" published back in 1922. Malinowski pointed out that

\section{The organisation of the tribe, and the anatomy of its culture must be recorded...} avenues:

...the goal of ethnographic field-work must be approached through three

2. Within this frame, the imponderabilia of actual life and the type of behaviour have to be filled in...

3. A collection of ethnographic statements, characteristic narratives, typical utterances, items of folklore and magical formulae has to be given as a corpus inscriptionum, as documents of native mentality. These three lines of approach lead to the final goal, of which an Ethnographer should never lose

2 Here is the list of these additional field trips and their duration: May 1989 - August 1989; July 1992 - September 1992; June \& July 1993; August \& September 1994; May \& June 1995; May \& June 1996; May \& June 1997; August \& September 1998; May \& June 2001; June 2003; July \& August 2004; June 2006, August \& September 2008, May \& June 2012. 
sight. This goal is, briefly, to grasp the native's point of view, his relation to life, to realise his vision of his world.

(Malinowski 1922: 24f.)

Malinowski, the master of Trobriand ethnography, managed to document a Corpus Inscriptionum Agriculturae Quriviniensis in his second volume of "Coral Gardens and their Magic" (1935 Vol II: 79-342). But he himself did not manage to come up with a holistic corpus inscriptionum for the Trobriand Islanders. One of the main aims I pursued during my long-term research on the Trobriand Islanders' language, culture and cognition was to fill this ethnolinguistic niche.

\section{Learning Kilivila as the basic prerequisite for doing my research}

However, the basic prerequisite for doing my research on the Trobriand Islands was to learn the language of the Trobriand Islanders. ${ }^{3}$ To gather data on such a complex topic like "ritual communication" I not only had to get a good understanding of the grammar and the lexicon of this Austronesian language, but I also had to unravel, learn and understand the pragmatic rules of this speech community to speak the language properly and adequately in various different speech situations and social contexts. This seems to be a trivial insight - in his essay "Considérations sur les diverses méthodes à suivre dans l'observation des peuples sauvages" published already in 1797, Joseph-Marie Degérando asked the critical question "How can we fancy to really observe people we do not understand and with whom we cannot talk?" - but it is a sad fact — if not scandalous - that up to the present day only a small minority of linguists and anthropologists doing field research in so-called "exotic" languages and cultures master the language of the speech community in which they do their research! ${ }^{4}$

Before we go medias in res, I first briefly introduce the Trobriand Islands, the Trobriand Islanders and some important aspects of their culture as well as their language Kilivila (see Senft \& Senft 2018: 7f.).

On his search for the missing ship La Pérouse, the French naval officer and explorer Joseph Antoine Bruni D'Entrecasteaux (1739-1793), discovered an island archipelago which he named after one of his officers on his ship "Espérance", Jean François Sylvestre Denis, comte de Trobriand (1729-1810). The indigenous name of the biggest island of this archipelago, which is now called Kiriwina, is Boyowa. The Trobriand Islands, a group of about 20 islands and islets, in the Solomon Sea are situated at the $151.04^{\circ}$ of Eastern Longitude and $8.38^{\circ}$ of Southern Latitude in the Milne Bay Province of Papua New Guinea. Kitava Island is an elevated coral island which rises to about $30 \mathrm{~m}$ at a central ridge. The other islands and islets are low-lying flat coral atolls. All islands are coral formations composed of coralline limestone. Most of them are fringed by coral reefs. The islands Kitava,

3 See also Senft 2008a; 2012a.

4 See also Dixon (1984: 199) where he criticizes the limitations of the approach of "asking questions over a desk" as follows: "it is no substitute at all for living with a language, observing it being used, and using it oneself" (see also Dixon 1984: 219). 
Kiriwina, Vakuta, Kaile'una, Muwa, Kuiawa, Munuwata, Tuma, and Simsim are populated. The islands are considered to be an important tropical rainforest ecoregion. The climate on the Trobriands is tropical. The average temperature is between $28^{\circ}$ and $30^{\circ}$, with maximal temperatures of about $35^{\circ}$ and minimal temperatures (at night) of about $22^{\circ}$. The humidity is very high throughout the year with an average of more than $90 \%$. The rainy season lasts from November till April with the northwest monsoon as the prevailing wind, the dry season lasts from May till October with a constant southeast trade wind blowing.

The Trobriand Islanders have become famous, even outside of anthropology, because of the anthropologist Bronislaw Kasper Malinowski, who did field research there between 1915 and 1918 (see Young 2004; also Senft 2006, 2009a). The Islanders belong to the ethnic group called 'Northern Massim' (see Haddon 1894: 184; also Liep 2015: 185). They are gardeners, doing slash and burn cultivation of the bush; their most important crop is yams. Moreover, they are also famous for being excellent canoe builders, carvers, and navigators, especially in connection with the ritualized 'Kula' trade, an exchange of shell valuables that covers the Massim area of the Melanesian part of the Pacific (see Malinowski 1922; Leach \& Leach 1983; Persson 1999). Other highly important features of the Trobriand Islanders' society are that it is matrilineal and follows the rule of patrilocality - or virilocal residence - which means that a newly married couple lives in the village of the husband (see Baldwin 1971: 246, 270ff).

Kilivila, the language of the Trobriand Islanders, is one of 40 Austronesian languages spoken in the Milne Bay Province of PNG (see Senft 1986: 6). It is an agglutinative language; its word order is rather free; the most frequent word order is SubjectVerbObject, but its general unmarked word order pattern is subjectprefixVerbObject(Subject). The Austronesian languages spoken in Milne Bay Province are grouped into 12 language families; one of them is labeled Kilivila. The Kilivila language family encompasses the languages — Budibud (or Nada, with about 200 speakers living on the Budibud Islands), - Muyuw (or Murua, with about 4,000 speakers living on Woodlark Island and on the populated islands Gawa, Iwa, Kwaiawata, Egum and Yanaba of the Woodlark Islands group - this group of islands is also called Marshall Bennetts Islands), and - Kilivila (or Kiriwina, and also Boyowa), with about 40,000 speakers; Kilivila is spoken on the islands Kiriwina, Vakuta, Kitava, Kaile'una, Kuiawa, Munuwata and Simsim). The languages Muyuw and Kilivila are split into mutually understandable local dialects. Typologically, Kilivila is classified as a Western Melanesian Oceanic language belonging to the Papuan-Tip-Cluster group (Senft 1986: 6).

In the preparatory phase of the project I quickly realized that Kilivila was not properly described at all. The little bits and pieces of information on Kilivila which I found in the literature turned out to be either erroneous or completely wrong (see Senft 1991: 27, 46). The only exception were the few notes on Kilivila scattered throughout Malinowski's Oeuvre (see e.g., Malinowski 1920). And unfortunately his second volume of "Coral Gardens and their Magic" titled "The Language of 
Magic and Gardening" published in 1935 presents magical formulae which have nothing to do whatsoever with the Kilivila variety which is spoken in everyday social interactions (I will come back to this fact below).

\subsection{Learning Kilivila based on "opportunistic" forms of data collection and everyday interactions with the Trobriand Islanders}

When I arrived on the Trobriands, one of the first things I did was to ask the missionary on Kiriwina Island, Father William Cunningham, to tell me the Kilivila equivalents for the English question words "who" (avela), "what" (avaka), and "where" (ambeya) and to translate the sentences "What is this" (avaka beya) and "I want to learn Kilivila" (magigu banukwali biga Kilivila) for me. When we arrived in Tauwema a few days later, Wulf Schiefenhövel, another colleague from the MPI in Seewiesen (who left the islands after 6 weeks), introduced us to the village community - he could speak Hiri Motu, a lingua franca of Papua New Guinea which some of the older people of Tauwema understood -, and the day after our arrival in my village of residence to be on Kaile'una Island, I started to collect data with the memorized question words and phrases listed above to compile a Kilivila-English wordlist. I also had an English-German picture-dictionary with me (Pheby \& Scholze 1979) - and it turned out that the pictures in this volume were excellent means to elicit words and even short sentences from my Tauwema consultants. I also approached people with my tape recorder indicating that I would like to record their speech; usually my attempts were answered by a friendly nod. And so I managed to record a broad variety of different speech data. I processed the data as soon as possible - with the help of at least two consultants who controlled my correct understanding of the recorded data - and then I transcribed the data using the International Phonetic Alphabet (IPA). These IPA transcriptions provided the basis for my phonetic/phonological analyses which allowed me to come up with the Kilivila orthography after I had returned from the field (Senft 1986: 14ff). In the first 2 weeks in Tauwema I could also work about half an hour or so per day with Uveaka, a young man who could speak English. Unfortunately he left the village to work on a ship. I was lucky to find a number of people who wanted to teach me their language - among them were my main consultants Nusai, a man in his late 30s who was the son-in-law of our chief Kilagola, Nusai's 14 year old son Pulia who attended school in our neighboring village Kaduwaga and who could speak a very basic variety of English, and Weyei, a man in his 60s, the local weather-magician and chief Kilagola's younger brother. Thus, my unguided language acquisition process of Kilivila took place in an almost monolingual situation - only my lexicographic sessions with Pulia and Nusai in which I tried to translate mainly with the help of Pulia the meaning of Kilivila words documented in my transcribed texts could be characterized as somehow bilingual.

My motivation to learn Kilivila as soon as possible was intensified in situations in which I realized my inability to communicate. It was very awkward and uncomfortable, for example, to sit in the evening in my house in the bright light of 
my Coleman lamp together with gradually arriving guests and to realize that after a few one-word utterances I just was able to smile around the room, but that most of the time I had to hide behind a novel. It was also weird to walk through the village with a group of young children in line behind me and to realize that they were singing a song every stanza of which ended in roaring laughter; what was most irritating in this situation was that the only word of the song I understood was my name. But the most important motivation resulted from my relationship with my teachers: I was completely aware of the fact that my potential failure in learning Kilivila would fall back on them: they would have to take the blame by their fellow villagers, they would be the ones to lose face in Tauwema if it turned out that I was a lousy learner!

I also learned rather quickly that my motivation had to be combined with a lot of humor and the ability to laugh about myself - everybody who learns a language in such a situation and in such a way as I did it is doomed to make mistakes - even severe ones. Many of these mistakes were simply based on not recognizing wordboundaries and the proper meaning of words. To give just one example: Seeing a beautiful net of a funnel-spider in the bush I asked my companions "Avaka beya?" - "What is this?" I noted down the answer "kapalilabwala" and translated it as "spider-web". Then I saw a spider and learned that the Kilivila word for it was "kapali". Checking my word-list at home I realized that I had noted down the word "bwala" and translated it as "house". This implied that I had to parse the utterance "kapalilabwala" as "kapali la bwala" which literally meant "spider its house" and which could be glossed as "spider-web". Other mistakes were more serious, as the following example illustrates (see Senft 2014: 1f.):

Every morning after I had gotten up and brushed my teeth, I would grab my towel and the little box that contained my soap, shampoo, hair brush and other articles we West-Europeans think to be absolutely necessary for having a bath and walked through the village to the path that leads to a fresh water grotto, about a tenminute walk into the bush southeast of Tauwema. Although everyone could infer from the things I carried where I was going, and although all the villagers knew after some time that this was part of my morning routine, people always asked me in the village or on the path to the grotto Ambe? - "Where?" - implying "Where are you going to?" At first I reacted with a smile and answered with the name of the grotto: Bugei. However, after some weeks - having made some progress in my language acquisition, I responded somewhat impatiently by either waving with my towel to the people who asked this (for me then rather silly) question or by simply answering $O$, kunukwali, bala Bugei makala yumyam - "Oh, you know, I will go (to the) Bugei like every day". After having responded to this question in this way for a few days, Weyei - my neighbor and one of my best informants and friends approached me and told me that I should always answer this question as exactly as possible. Thus, after some further progress in learning the language I could react to the question Ambe? in the appropriate Trobriand way, answering for example: Bala bakakaya baka'ita basisu bapaisewa - "I will go, I will have a bath, I will return, 
I will stay (in the village), I will work". With Weyei's help I came to understand that this question was in fact a greeting formula. People who meet in the Trobriands and who want to indicate that they care for each other do not use greeting formulae such as Bwena kaukwa - "good morning", but instead ask each other where they are going. This question is always answered as truthfully and as comprehensively as possible (as in the example given). This has a practical reason: all paths on Kaile'una Island and most paths on the other islands belonging to the Trobriand group are just small trampled paths that often lead over sharp coral rocks where it is quite easy to hurt one's foot or leg. Also, sometimes the paths cross a grove of coconut trees, and it has also happened that people on these paths have been rather severely hurt by falling coconuts. Moreover, Trobriand Islanders are very much afraid of the kosi. According to their belief the kosi are ghostly spirits of dead persons who were not properly mourned immediately after their deaths and who therefore terrify the living. The apparition of a kosi may frighten someone in the jungle in such a way that they might lose their orientation. Therefore, the answer to this form of greeting functions to secure one's way and one's safe arrival at one's destination. If people do not show up after a certain time at the places mentioned in their answers to the greeting question, their fellow villagers and friends will look for them. Thus, being greeted with this question is a sign that the community cares for the person. It is a daily routine that serves the function of social bonding. And it is considered so important that Trobrianders who are not greeted in this way at least by their fellow villagers will conclude that they must have committed some serious offense against the community. A village community that does not greet one of its fellow villagers with this question indicates that it no longer cares for this person. So it was a completely inappropriate reaction when I - sometimes quite conceitedly - smiled about what I first thought to be a silly question. On the contrary, being greeted with this question by the people of Tauwema after only a few days in their village was a first sign of their good will and intention to integrate me into the community. ${ }^{5}$

As a newcomer in the Trobriand speech community I hardly knew anything about the conventions, rules and regulations with respect to how the Trobriand Islanders use their language Kilivila in social interactions, what kind of meanings their words, phrases and sentences convey in what kind of contexts and what kind of functions their use of language fulfills in and for its speakers' communicative behavior. To gain this kind of knowledge requires the study of the culture-specific forms of the Trobriand Islanders' language use. To learn the pragmatic rules that are valid in a speech community is as important as to acquire the lexicon and the grammatical algorithm of their language!

From the very beginning my language acquisition process went hand in hand with my processing and transcribing of my data with the help of my three language teachers and some other consultants. This work resulted in first hypotheses about

5 I provide a list of mistakes like this one in Senft (1995). 
syllable- and word-boundaries which I could verify or falsify with my gradually growing Kilivila-English word-list (to be later transformed into a basic dictionary). This word-list was based on a corpus of audio-documented speech data encompassing a variety of text categories or genres which represented both forms of everyday verbal interactions and of forms of ritual communication. I documented these texts in a completely opportunistic manner - that is to say, whenever I had the chance to tape-record verbal interactions of all kinds, I did it. My interest in their language and culture and the progress I made in acquiring Kilivila was very much appreciated by the people of Tauwema. For me this kind of empirical research was a fascinating approach to linguistics, and the interest I evinced not only in their language but also in their culture, their customs and their ways of living was very positively and openly acknowledged by the Trobrianders. This overall commitment for my research was essential for its success. The work of all field researchers ultimately depends on the good will of their consultants and their willingness to cooperate in the planned projects. My experience on the Trobriands totally confirms William Labov's (1972: 114f) observations about the behavior of field researchers:

A field worker who stays outside his subject, and deals with it as a mere excuse for eliciting language, will get very little for his pains. Almost any question can be answered with no more information than was contained in it. When the speaker does give more, it is a gift, drawn from some general fund of good will that is held in trust by himself and the field worker. A deep knowledge implies a deep interest, and in payment for the interest the speaker may give more than anyone has a right to expect. Thus the field worker who can tap the full linguistic competence of his subjects must acquire a detailed understanding of what he is asking about, as well as a broad knowledge of the general forms of human behavior.

Indeed, after a few weeks of my activities in Tauwema, inhabitants of the village themselves approached me and offered to provide me with some interesting texts or invited me to participate in interesting village activities or to accompany them to our neighboring villages to observe special village activities.

Thus, in the course of the time I was more and more accepted as a member of the village community with all the rights and responsibilities to participate in cultural activities in Tauwema. This enabled me to collect a growing corpus of speech data which provided me with crucial grammatical insights into the phonology, the morphosyntax, the semantics and the pragmatics of Kilivila. I managed to gain these insights not only by processing and transcribing these texts with the help of my consultants, but also by actively speaking with the Trobriand Islanders about my experiences, my everyday observations and my data - with the risk of making funny speech errors by producing ridiculous words or phrases. The very positive reaction of the people of Tauwema to these mistakes was that they first laughed about them, of course, but then immediately corrected the mistakes including all cases of incorrect or inadequate speech behavior. And they kept doing 
this up to my very last day on the islands in 2012 - although during the cause of the years these interventions became rarer and rarer.

But again, back to the beginnings in 1982/83 and the general course of my language acquisition process then: after about 10 weeks living in Tauwema I had a first breakthrough in my more or less unguided language acquisition process I unveiled the word-formation processes of verbal expressions in Kilivila and came up with the first paradigm providing the relevant morphemes for the indication of persons and numbers (1st, 2nd. and 3rd Person Singular, Dual inclusive, Dual exclusive, 1st Person Plural inclusive, 1st Person Plural exclusive, 2nd Person Plural and 3rd Person Plural) and 4 different series of Tense/Aspect/Mood-markers (neutral/unmarked; incompletive action/future/irrealis; completed action; habitual action/optative). I also learned 10 new Kilivila words every day and tried to memorize the names of the inhabitants of Tauwema (with the help of a census we made using polaroid photos with personal data written down on file cards for mnemotechnic reasons). After about 4 months I could write a first and very basic sketch of the grammar; after about 8 months of my staying in Tauwema I could follow and conduct conversations, and at the end of my 1983 field trip I could speak Kilivila in a way which did not only please my language teachers. ${ }^{6}$

\subsection{Learning Kilivila in a more theoretically informed way}

As mentioned above, in the preparatory phase of my field research I carefully read Malinowski's publications on the Trobriand Islanders. It surprised me to realize that the Trobrianders obviously had a lot of metalinguistic expressions to refer to different genres or text-categories. In discussing the 'Mythology of the Kula' in his famous masterpiece 'Argonauts of the Western Pacific', for example, Malinowski (1922: 299) points out that the Trobriand Islanders'

...folk-lore, that is, the verbal tradition, the store of tales, legends and texts handed on by previous generations, is composed of the following classes: first of all, there is what the natives call libogwo, 'old talk', but which we would call tradition; secondly, kukwanebu, fairy tales, recited for amusement, at definite seasons, and related avowedly untrue events; thirdly, wosi, the various songs, and vinavina, ditties, chanted at play or under other special circumstances; and last, not least, megwa or yopa, the magical spells. All these classes are strictly distinguished from one another by name, function, social setting, and by certain formal characteristics... ....[T]he 'old talk', the body of ancient tradition, believed to be true, consists

6 Interesting compilations of other field-researchers' statements about their competence in the language of the community they researched are provided by Fischer (2000: 5-12), Franklin (1992), and Werner (1994: 79-86). These statements vary considerably. Raymond Firth (1957: 6), for example, claims that after three weeks of his staying with the Tikopia he only worked with them in their own language. Hortense Powdermaker $(1966 ; 66)$ on the other hand confessed frankly that she never managed to properly learn the language of the Lesu in New Ireland. And Malinowski (1935: xi) asserts: "It took me about a year to speak easily, and I acquired full proficiency only after some eighteen months of practice, that is, towards the middle of my second expedition". 
on the one hand of historical tales, such as the deeds of past chiefs, .... stories of shipwreck, etc. On the other hand, the libogwo class also contains what the natives call lili' $u$ - myths, narratives, deeply believed by them, held by them in reverence, and exercising an active influence on their conduct and tribal life.

Malinowski then elaborates on these "lili' $u$ " differentiating three groups of 'mythical folk-lore:

1. The Oldest Myths, referring to the origin of human beings....

2. Kultur myths... stories about ogres and their conquerors... [and]

3. Myths in which figure only ordinary human beings, though endowed with extraordinary magical powers.

(Malinowski 1922: 304 f.)

Malinowski's discussion of genres in Kilivila and his reference to the Kilivila metalinguistic terms for these genres and speech varieties were fascinating and the more I got confident in my gradually growing competence in speaking Kilivila, the more I tried to discuss forms of the Trobianders' metalinguistic awareness manifest in their metalinguistic vocabulary with my consultants. It turned out that the Trobriand Islanders' understanding of genres and speech varieties is much more complex than Malinowski suspected.

In his essay "The problem of meaning in primitive languages" Malinowski (1923: 316) pointed out "that language in its ... original form has an essentially pragmatic character, that it is a mode of behaviour, an indispensable element of concerted human action". My intensive research on the Trobriand Islanders' metalinguistic vocabulary and their metalinguistic concepts provides unequivocal emic support for this important insight. I want to emphasize explicitly that the salient relevance of the concepts codified by these metalinguistic terms is so important for the Trobriand speech community that it is one of the most important characteristics of the language to be recognized in anthropological linguistic field research. Whoever wants to learn and speak Kilivila properly has to grasp them, because the understanding of these concepts is compulsory for the pragmatically adequate use and understanding of this language.

In this second phase of my language acquisition process which was guided by Malinowski's first and more or less anecdotal insights in the importance of Kilivila metalinguistics, I learned that the Trobrianders distinguish not only local varieties - or dialects — of Kilivila (see Senft 1986: 6ff), but also non-diatopical registers that I have called "situational intentional varieties". ${ }^{7}$ I refer with this label to registers or varieties of Kilivila that are used in a given special situation and produced to pursue certain intentions (see Senft 1986: 124ff.). To my knowledge, Kilivila native speakers differentiate and metalinguistically label eight of these varieties, two general and six specific ones. They form the basic framework

7 There is no metalinguistic expression in Kilivila that can be compared with this - etic concept of 'situational intentional varieties'. However, it is obvious that the Trobriand Islanders differentiate these varieties metalinguistically. 
necessary for adequately describing genres in this Austronesian language, because the various genres that the Trobriand Islanders differentiate and also label metalinguistically are - generally speaking - constitutive for these situationalintentional varieties. I have documented and illustrated the Trobriand Islanders' emic typology ${ }^{8}$ of these registers and their genres and analyzed their communicative interactional functions in detail in a special monograph (Senft 2010). In what follows I will first briefly present these varieties and their constitutive genres (see Senft 2010: 10ff) and then justify the claim I made above that the understanding of these concepts is compulsory for the pragmatically adequate use and understanding of Kilivila.

\section{1. 'Biga bwena' — 'Good speech'}

The general situational-intentional variety 'Biga bwena' — 'good speech' subsumes all utterances in all but one of the Kilivila language varieties that adequately match in style and lexicon the respective speech situation in which interactants are involved. Thus, with the exception of its antagonistic variety ' biga gaga' ('bad speech'; see below), the 'biga bwena' concept applies to all other Kilivila speech varieties, emphasizing the adequate use of language in a given communicative context. This superordinate register is constituted by the appropriate production of all genres that are themselves constitutive for all other situational-intentional varieties except for the 'biga gaga' register and especially except for the specific genre 'matua' ('insults, swear words') that co-constitutes the 'biga gaga' variety. The basically aesthetic label 'biga bwena' is used to qualify speakers' utterances with respect to a given standard norm of appropriate speech behaviour. Someone who is famous for using 'biga bwena' enjoys a good reputation and much social prestige, irrespective of the status within the otherwise highly stratified clan and subclan hierarchy of the Trobriand society.

\section{2. 'Biga gaga' - 'Bad speech'}

As mentioned above, the 'biga gaga' variety is just the opposite of the 'biga bwena' register. With the exception of its antagonistic variety 'biga bwena' (see 1) but also with the exception of (almost all aspects and constitutive genres of) the 'biga sopa' variety (see 8), this second general situational-intentional variety

8 The emic/etic distinction (from phonemic versus phonetic) made here goes back to Kenneth Pike (1954). Gustav Jahoda (1995: 129) quotes French (1963: 398) who defines the two approaches as follows:

Pike identifies the emic approach as a structural one. The investigator assumes that human behaviour is patterned, even though the members of the society being studied may not be aware of many units of the structuring. In Pike's view, the goal of the emic approach is to discover and describe the behavioural system in its own terms, identifying not only the structural units but also the structural classes to which they belong.

In contrast, an etic approach can be characterized as an external one.

Items of behaviour are examined not in the light of the systems in which they occur, but rather in that of criteria brought to bear on them by the observer. 
applies to all other Kilivila speech varieties, emphasizing the inadequate use of language in a given communicative context. The basically aesthetic label is also used to qualify speakers' utterances with respect to a given standard norm of speech behaviour. The use of this variety generally implies the distancing of speakers from their addressees. It is aggressive and insulting. Its use is - at least officially - not approved by the speech community and quite often sanctions are imposed against someone who produces such 'bad speech'. This superordinate register is constituted by the inappropriate production of all genres that are themselves constitutive for all other situational-intentional varieties except for the 'biga bwena' and the 'biga sopa' variety. Moreover, this superordinate register is co-constituted by the specific genre 'matua' which subsumes all kinds of - seriously meant and produced insults, swear words, obscene speech and the verbal breaking of taboos.

3. 'Biga tommwaya / Biga baloma' - 'Old people's speech / Speech of the spirits of the dead'

This archaic variety is very rarely used in everyday discourse and conversation. If words or phrases that are characteristic for this register are used in everyday interaction, they serve the function of sociolinguistic variables which indicate high status of the speaker. This situational-intentional variety is used in highly ritualized contexts. The register is constituted by specific songs sung during the harvest festivals and during a certain period of mourning; these songs are summarized under the specific genre label 'wosi milamala' — 'songs of the harvest festival'. The majority of these songs describe the carefree 'life' of the spirits of the dead in their 'underworld paradise' on Tuma Island. Moreover, magical formulae also represent many features of the 'biga baloma / biga tommwaya' register. However, because other features are also constitutive for these formulae, the Trobriand Islanders classify them as constituting a variety of their own, namely the 'biga megwa' - the 'magic speech' register (see 4.). Both magical formulae and songs have been passed on from generation to generation with the immanent claim to preserve their linguistic form. The majority of the people citing these magical formulae and singing these songs do not or no longer understand their semantic content, their meaning.

\section{4. 'Biga megwa' - 'Magic speech'}

As mentioned above, this language variety is very similar and closely related to the 'biga tommwaya / biga baloma' variety. However, the variety not only encompasses archaic Kilivila words, syntactic constructions, and shades of meaning, but also so-called magical words and loan words from other Austronesian languages. Malinowski contrasts this variety which he calls 'megwa la biga' ('magic its speech') with ordinary speech, to which he refers with the label 'livala la biga' ('speech its language, spoken (everyday) language'; see Malinowski: 1935, Vol. II: 225$)^{9}$. This variety is highly situation dependent, of course, and very

9 I have never heard this latter expression on the Trobriands. 
onomatopoetic and metaphoric. Trobrianders differentiate between various forms of magic. All these specific forms of magic have specific names, however, they are all subsumed under the genre label ' $m e g w a$ '. And it is this genre that constitutes the 'biga megwa' variety.

\section{5. 'Biga tapwaroro' - 'The language of the church'}

This variety of Kilivila is used in church services and other Christian rituals. When the Overseas Missions Department of the Methodist Church commenced work in the Trobriand Islands in 1894, its headquarters was established in Kavataria on Kiriwina Island. Till 1989 this variety was heavily based on the language variety spoken in Kavataria and its neighboring village Oyabia (the dialect is called 'biga galagoki'); moreover, it showed traces of archaic language and had borrowed a number of loan words from the Dobu language. The Methodists started their missionary work in Milne Bay on Dobu Island and used Dobu as their lingua franca in the area. The Trobrianders use the label 'biga tapwaroro' to refer to the variety represented in Christian rituals and texts that are associated with the church service. Two genres are constitutive for this register: 'tapwaroro' refers to all forms of speech produced during various forms of church services, and 'wosi tapwaroro' 'church song' - is the label for the genre 'Christian hymns'. The 'wosi tapwaroro' sometimes represent hymns that are sung in neighboring languages like Dobu or Muyuw, and the 'tapwaroro' genre that co-constitutes this variety represents a formal language variety typically used by older Trobriand Islanders of high status which is slightly different from modern Kilivila used in profane, secular contexts. Nevertheless, the 'biga tapwaroro' label of this variety emphasizes the Christian context of these forms of speech and songs.

\section{6. 'Biga taloi' - 'greeting and parting speech'}

This variety just refers to the Trobriand forms of greeting and parting as well as to the formulae for politely opening and closing public speeches. These relatively few forms and formulae are subsumed under the genre label 'taloi' — and this genre constitutes the 'biga taloi' register.

7. 'Biga pe 'ula / Biga mokwita' — 'Heavy speech / hard words / true (direct) speech

This variety is rather rarely used; but when it is used, the directness of the speakers indicate that they are completely aware of the fact that they have to take all risks of stripping away ambiguity and vagueness with which speakers normally can disguise their own thoughts - a feature characteristic for the 'biga sopa' variety (see 8) - and that they can stand to argue publicly in terms of the heavy ('pe'ula') dimension of truth ('mokwita'). Thus, the use of this variety implies an important personal and social impact of what is said; moreover, its use is explicitly marked by speakers declaring that what they are going to say now or what they have said is not 'sopa' but 'biga pe'ula' or 'biga mokwita'. The speakers' commitment in the marked sense finds its expressions in ritualized formulae, like, for example, 
'Besatuta balivala biga mokwita!' - 'Now I will talk true language! The following four genres are co-constitutive of this register: 'yakala' — 'litigations', 'kalava' 'counting baskets full of yams', 'kasolukuva' — 'mourning formulae', and 'liliu' — 'myth'.

8. 'Biga sopa' — 'Joking or lying speech, indirect speech, speech which is not vouched for'

This variety is absolutely characteristic for the Trobriand way of speaking it constitutes the default register of Trobriand discourse, so to speak. It is based on the fact that Kilivila, like any other natural language, is marked by features that include 'vagueness' and 'ambiguity'. Both these features are used by its speakers as stylistic means to avoid possible distress, confrontation, or too much and - for a Trobriand Islander at least - too aggressive directness of certain speech situations. If hearers signal that they may be insulted by a certain speech act, speakers can always recede from what they have said by labeling it as 'sopa', as something they did not really mean to say. Thus 'sopa' represents the speakers' "unmarked non-commitment to truth" (Bill Hanks, p. c.). Trobriand etiquette then prescribes that hearers must not be offended at all by those utterances that were explicitly labeled as 'sopa'. If they feel offended and display this feeling publicly, then they lose face. The Trobriand Islanders employ this variety in everyday conversation, in small talk, in flirtation, in public debates, in songs and stories as a means of rhetoric to avoid possible conflicts and to relax the atmosphere of the speech situation. The 'biga sopa' variety also contributes to put forward arguments because it allows speakers to disguise their thoughts verbally and to disagree in a playful way without the danger of too much personal exposure. Moreover, the 'biga sopa' variety is used for mocking people. As a means of irony and parody it can be used to criticize certain forms of sociologically deviant behaviour, relatively mildly asking for immediate correction. Finally, the 'biga sopa' variety offers the only license for the verbal breaking of almost all taboos and thus for the licensed use of 'biga gaga' (see 2.) - not only for adults but also for children. The following genres constitute the 'biga sopa' variety: 'sopa' — 'joke, lie, trick', 'kukwanebu sopa' — 'story, joke in form of a story', 'kukwanebu(1)' — 'tale', 'kasilam' 'gossip', 'wosi' — 'songs', with a number of separately named subvarieties, 'butula' — 'personal mocking songs', 'vinavina' — 'mocking ditty' — with a number of named subvarieties, 'matua' — 'some insults and swear words as well as obscene speech', and 'sawili' — 'harvest shouts'.

\section{Other genres}

The Trobriand Islanders also differentiate a number of genres that oscillate between the 'biga sopa' register and the 'biga mokwita' variety. They classify them as 'kena biga sopa kena biga mokwita' - 'either joking speech or true speech'. These genres are 'kukwanebu(2)' — 'story' (fiction and non-fiction), 'kavala' 'personal speech', 'luavala' - 'admonishing speech', '-kasemwala-' — '(actions of) propositioning and/or seduction', and '-nigada-' — '(actions of) ... requesting'. 
My insights in the utmost importance of understanding the Trobrianders' metalinguistic concepts as being compulsory for the pragmatically adequate use and understanding Kilivila were actually based on the severest mistake I made in the course of my field research on the Trobriands - namely on my breaking of the Trobrianders' most important taboo during a wedding ceremony I observed in 1983 - and on my attempts to reconcile myself with the person I had insulted in this way afterwards (see also Senft: 2017a; 2018).

One morning in 1983 my wife and I saw Itakeda sitting together with Yau on the veranda of his house. This meant that the girl had decided to marry her boyfriend - and her family as well as Yau's family were busily and happily preparing for a festive exchange of gifts between the two families. Itakeda's father was even preparing to kill a pig. After we came back from our morning bath, we sat down on a veranda of one of the neighbors of Itakeda's father. It was more or less by chance that this was the house where Itakeda's best girlfriend Bomsamesa lived. She was sitting at my right side and her older brother crouched beside my wife and observed the preparation of this little feast in honor of the newly married couple. After a while I asked Bomsamesa: "When will you marry?" And immediately hell broke loose: Bomsamesa's mother who was standing behind us came on me like a fury, scolded me and actually chased me away! Back in my house I realized that I had just violated the most important taboo of the Trobrianders the Brother-Sister Taboo! It is taboo for siblings to know anything about one another's erotic affairs (see Malinowski 1929: 433ff). I had carefully read Malinowski before I went to the Trobriands, I knew about the taboo, but in the actual situation I really behaved like a bull in a china shop. I tried my best to regain the friendship of Ibova again. It took some time, though, and many sticks of tobacco as peace offerings. One afternoon I was close to her house while she was playing cat's cradle - or string figures - for her little grandchildren. And I was flabbergasted when I heard her reciting the following verses - realizing that the little kids obviously had a lot of fun with their granny:

Tobabane, Tobabane
kwakeye lumta!
Kwalimati.
Kusivilaga,
kuyomama.

$$
\begin{aligned}
& \text { Tobabane, Tobabane, } \\
& \text { you fuck your sister! } \\
& \text { You fuck her to death. } \\
& \text { You turn around, } \\
& \text { you are weak and tired. }
\end{aligned}
$$

It was obvious that this game referred to a case of incest between brother and sister - the extreme case with respect to the violation of the brother-sister taboo. I asked Ibova why she recited these pornographic verses to these very young children, on the one hand, whereas on the other she was recently so furious with me because of my - according to my standards - innocent question. She laughed at me for the first time after my faux pas and said that this was something completely different. She was only playing with her grandchildren and this play was just sopa! We had obviously made peace with each other at that moment, but what the heck did she mean? 
My consultants told me that the biga sopa - the "joking or lying speech", the "indirect speech", the "speech that is not vouched for" — is absolutely characteristic for Trobriand forms of talk; it constitutes the default register of Trobriand discourse. On the basis of my consultants' explanations of the concept of 'sopa' I could come up with the definition and description of this variety of Kilivila and I could list its constitutive genres (see 8 above). Because of the fact that the biga sopa variety offers the only license for the verbal breaking of taboos and thus for the licensed use of biga gaga Ibova had no problems in reciting the bawdy verses that accompany the Tobabana string figure to her little grandchildren. The various biga sopa genres that include biga gaga characteristics - like the ditty Ibova recited - also serve the function of so-called "safety valve customs" (Heymer 1977: 187; Eibl-Eibesfeldt 1984: 492 ff).

This ethological concept needs some explanation: Every society puts some of its realms, domains and spheres under certain specific taboos. However, the stricter the society is in regard to its observance of these taboos, the more these taboos are ignored. But a society can secure its members' observance of certain taboos, especially of taboos that are important for its social construction of reality (Berger and Luckmann 1966), by allowing the discussion of its taboos - especially of the sociologically less important ones - as topics of discourse. It may even allow its members to imagine the ignorance of taboos - in a fictitious way, of course. And this is exactly how and why safety valve customs develop. Texts and utterances that show features of biga gaga are first of all classified as sopa - as play, as something fictitious in Trobriand society. The biga sopa thus generates a forum where the breaking of taboos - and thus the use of (milder forms of) "bad language" — is allowed, if it is done verbally! This forum permits a specially marked way of communication about something "one does not talk about" otherwise.

Thus, the biga sopa variety channels emotions, it keeps aggression under control, and it keeps possibilities of contact open. This concept with it tensionreleasing functions secures harmony in the Trobriand society and contributes to maintaining the Trobriand Islanders' social construction of their reality.

It is obvious that the understanding of this metalinguistic concept is crucial for everybody who wants to learn Kilivila and to use the language situation-adequately in social interactions - and it goes without saying that this insight also holds for the other situational-intentional varieties of Kilivila mentioned above. The Trobriand Islanders' metalinguistic vocabulary codifies extremely important aspects of their own indigenous or emic theory of their language!

Once I had gained these important insights into the metalinguistics of Kilivila situational-intentional registers and their constitutive text-categories, I systematically collected data illustrating the genres of these varieties and discussed them intensively with my consultants. In the course of this documentation - the compilation of my Kilivila corpus inscriptionum which was guided by the Trobianders' own - emic - metalinguistic concepts, I also learned much about the conventions, rules and regulations with respect to how the Trobriand Islanders' 
use their language in social interactions, what kind of meanings their words, phrases and sentences convey in what kind of contexts and what kind of functions the use of language fulfills in and for its speakers' communicative behavior. The acquisition of these pragmatic rules that govern the adequate and appropriate use of Kilivila in different communicative contexts was decisive for reaching my aim to meet Malinowski's (1922: 24f.) claim to "grasp the native's point of view, his relation to life, to realize his vision of his world".

\section{My Kilivila corpus inscriptionum - a brief survey and a critical acclaim}

Immediately after I returned from my 1983 fieldtrip I started to compile the grammar and the Kilivila-English / English-Kilivila dictionary (which was published in 1986), because I was convinced that after my 15 months of fieldwork I was at the height of my acquired speech competence in Kilivila. Already in 1901 Georg von der Gabelentz pointed out the following:

Ich wiederhole es, dieser Aufgabe [eine Sprache zu beschreiben] ist nur der gewachsen, der die Sprache praktisch beherrscht: das wissenschaftliche Kennen, das Erkennen und Beurtheilen setzt ein Können voraus; die wissenschaftliche Darstellung wird nichts Anderes sein, als eine sachgemäße Erklärung dieses Könnens. Es ist dies ein Zustand, dessen sich der Grammatiker bewußt sein muß, und in welchem er sich Eins weiß mit dem Volke, dessen Sprache er lehren will

$$
\text { (von der Gabelentz 1901: 82) }{ }^{10}
$$

It was only on the basis of my speech competence in Kilivila that I could collect natural speech data in the Kilivila speech community. The will to learn the local languages and the effort to speak it facilitates the researcher's establishment in her or his field. The gradually growing knowledge of the language opens up insights which are extremely difficult to gain otherwise. If we accept that one of the most important aims of research within the humanities is to understand meaning, than it is obvious that the royal road to reach this aim is speech, communication, verbal interaction. On the basis of my grammar it was easy to enhance the accessibility and analysis of almost all kinds of speech data I collected throughout my research on the Trobriand Islanders' language, culture and cognition. However, it goes without saying that there were some grammatical phenomena which remained problematic for me to describe in an adequate and appropriate way. In Senft (1994) I provide a list of these cases with an explanation why I could not properly cope with them. Among these cases were the four series of possessive pronouns which

10 This quote translates as follows [my translation, G.S.]:

"I repeat, only somebody who commands a language can meet this challenging task [to describe a language]: scientific knowledge, recognition and assessing requires competence; the scientific presentation cannot be anything but an appropriate explanation of this competence. This is a condition a grammarian needs to be aware of and in which he is at one with the people whose language he wants to teach." 
can also be analyzed as possessive or relational classifiers. On the basis of my publications Matthias Passer re-analyzed the data in his $\mathrm{PhD}$ thesis on "The Typology and Diachrony of Nominal Classification" in which he presents - among many other fascinating research results - an elegant and convincing model of possessive marking in Kilivila (Passer 2016: 32ff).

During my field trips in 1982/83 and 1989 I especially collected data that documented different forms of ritual communication (see e.g., Senft 2009b) and specific grammatical and semantic phenomena like the system of nominal classification in Kilivila (Senft 1996; 2008b), complex serial verb constructions (Senft 2008c) and the inventory and use of color terms (1987; 2012b). The data on ritual communication fit into the Trobriand Islanders' metalinguistic typology of genres and the speech varieties constituted by them.

With the exception of the genres 'yakala' - 'litigations' (which I could not observe during my field research) and ' $k a v a l a$ ' — 'intimate personal speeches', and '-kasemwala-' - 'propositioning, seducing' (which I did not even try to document because of ethical reasons), I have illustrated all the other genres and thus the situational-intentional varieties of Kilivila in my Kilivila corpus inscriptionum.

As pointed out above and elsewhere (see Senft 2010: 276ff), speakers of Kilivila recognize speech genres because of their specific linguistic and/or contextual features and because of their being embedded in specific situative contexts, and they have no difficulties whatsoever in noting when a speaker is shifting from one genre to the other. Whoever wants to speak and understand Kilivila properly must acquire this ability to recognize these genres, to assign them to the situational-intentional variety which they (co)-constitute and to understand their pragmatic function in, and for, the Trobriand Islanders' speech community.

To my knowledge, the Trobriand Islanders' typology of situational-intentional varieties and their constitutive genres documented in my published and/or accessible parts of my Kilivila corpus is as exhaustive as possible. ${ }^{11}$ However, I want to emphasize here that this claim of 'exhaustiveness' only refers to varieties and genres that are metalinguistically labeled in Kilivila. Malinowski pointed out that the Trobriand Islanders realize the difference between myth and historic account, although they do not mark the difference with specific metalinguistic terms. That is to say, the realized difference between myth and historic account is not articulated in emic categories. During my long-term fieldwork I have also collected a number of descriptions of how to do certain things (like building a canoe, making a sail, burning lime, making a grass-skirt, etc.) and I have documented how mothers talk with their babies; these 'ways of speaking' are not differentiated by specific metalinguistic labels from other forms of talk in Kilivila, either. Thus, I am aware of the fact that my description of the Kilivila 'ways of speaking' purely in terms of emic genres is not complete in the strict sense of the term (see also Sherzer 1983:16). I am also aware of the fact that Duranti's (1988:

11 See my list of publications: https://www.mpi.nl/people/senft-gunter/publications and especially Senft (2010). 
220) critical assessment of the ethnography of speaking paradigm applies to my approach as well:

A possible criticism of speech-event analysis is that it tends to select strips of interaction that are labeled by a culture, but it may overlook those interactions which are not recognized as units of some sort by the members. It should be mentioned here that, although the presence of a lexical term for a given activity or 'strip of interaction' is only one level of local organization of experience - perhaps the most obviously ideological — the lack of a term for any given such 'strip' is an interesting clue for fieldworkers.

However, my corpus inscriptionum for Kilivila provides such a great variety of 'ways of speaking' and kinds of speech that I think I can live with this criticism, especially given the fact that I am aware of the limits of my endeavor.

Besides my guided collection of speech data which illustrate the Trobriand Islanders' metalinguistic typology of registers and their constitutive text categories I also collected data on specific grammatical phenomena like "nominal classification" and "serial verb constructions" as well as data at the interface of language, culture and cognition manifest in semantic domains like "space and spatial conceptualization" (Senft 2001) and in domains characterized by so-called 'ineffables' like "the emotions" (Senft 2017a\&b) and "the senses" (Senft 2011). These research projects provided important insights into the relationship between language, culture and cognition within the Kilivila speech community.

With respect to the discussion of my Kilivila corpus inscriptionum it is also interesting to note that there are no proverbs in Kilivila, that there are no poems, either (despite the fact that some of the songs, especially the 'wosi milamala' are highly poetic), and that there are no forms of drama (despite the fact that singing the 'wosi gilikiti' during a game of Trobriand cricket is a highly staged event and a kind of dramatic performance).

Finally, I want to emphasize once more that with the situational-intentional varieties and their constitutive genres I documented in my published data and my overall Kilivila corpus, I have provided the Trobriand Islanders' indigenous emic $^{12}$ - framework for, and at the same time illustrated, the corpus inscriptionum Kiriwiniensium Malinowski asked for (and partly founded himself). I have also described the functions these varieties and their constituting genres fulfill with respect to the Trobriand Islanders social construction of reality. The salient relevance of these situational-intentional varieties and the genres that constitute them is so important for the speech community that it is one of the most important characteristics of the language to be recognized in anthropological linguistic field research. To repeat it once more: whoever wants to learn, speak and describe Kilivila properly has to grasp them, because the understanding of these concepts is compulsory for the adequate use and understanding of this language. All speakers of a natural language must learn and acquire the rules of the verbal and nonverbal

\footnotetext{
12 See footnote 8 above.
} 
communicative behavior that are valid in, and hold for, their speech community. In the course of this learning process one of the most important objectives is to understand and to duplicate the construction of the speech community's common social reality (see Senft 2014: 86ff). Thus, whoever wants to research the role of language, culture and cognition in social interaction must know how the researched society constructs its reality. Researchers need to be on 'common ground' with the researched communities, and this common ground knowledge is the prerequisite for any successful research on language, culture and cognition manifest in social interaction. An as exhaustive as possible corpus inscriptionum of a language provides a sound basis for anybody who wants to - or needs to - acquire this common ground status. This is the most important prerequisite for all attempts "to grasp the native's point of view, his relation to life, to realize his vision of his world" (Malinowski 1922: $24 \mathrm{f}$ ).

(C) Gunter Senft, 2020 cc) creative

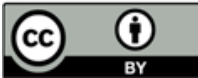

This work is licensed under a Creative Commons Attribution 4.0 International License https://creativecommons.org/licenses/by/4.0/

\section{REFERENCES}

Baldwin, Bernard. 1971. Dokonikani. Cannibal Tales of the Wild Western Pacific. Pekina: Typoscript. $<$ http://trobriandsindepth.com/myths.html>

Berger, Peter L. \& Luckmann, Thomas. 1966. The Social Construction of Reality. A Treatise in the Sociology of Knowledge. New York: Doubleday.

Degérando, Joseph-Marie. 1797. Considérations sur les diverses méthodes à suivre dans l'observation des peuples sauvages (= Erwägungen über die verschiedenen Methoden der Beobachtung der "wilden Völker". In Sergio Moravia (ed.), Beobachtende Vernunft. Philosophie und Anthropologie in der Aufklärung, 219-251. Frankfurt am Main: Ullstein).

Dixon, Bob. 1984. Searching for Aboriginal Languages. Memoirs of a Field Worker. St. Lucia: University of Queensland Press.

Duranti, Alessandro. 1988. Ethnography of speaking: toward a linguistics of praxis. In Frederick J. Newmeyer (ed.), Linguistics: The Cambridge Survey. Volume IV Language: The Socio-Cultural Context, 210-228. Cambridge: Cambridge University Press.

Eibl-Eibesfeldt, Irenäus. 1984. Die Biologie des menschlichen Verhaltens. Grundriß der Humanethologie. München: Piper.

Firth, J. Raymond (ed.), 1957. Man and Culture - An Evaluation of the Work of Bronislaw Malinowski. London. Routledge.

Fischer, Hans. 2000. Wörter und Wandel. Ethnographische Zugänge über die Sprache. Berlin: Reimer.

Franklin, Karl. 1992. On language learning claims of ethnographers. In Tom Dutton, Malcolm Ross \& Darrell Tryon (eds.), The Language Game: Papers in Memory of Donald C. Laycock, 589 - 597. Canberra: Pacific Linguistics.

French, David. 1963. The relationship of anthropology to studies in perception and cognition. In S. Koch (ed.), Psychology: A Study of a Science, Vol 6, 388 - 428. New York: McGrawHill. 
Gabelentz, Georg von der. 1901. Die Sprachwissenschaft, ihre Aufgaben, Methoden und bisherigen Ergebnisse. Zweite, vermehrte und verbesserte Auflage. Herausgegeben von Dr. Albrecht Graf von der Schulenburg. Leipzig: Tauchnitz. (Neuauflage: Mit einer Studie von Eugenio Coseriu neu herausgegeben von Gunter Narr \& Uwe Petersen. Tübingen: Tübinger Beiträge zur Linguistik 1969; 2. Auflage 1972).

Haddon, Alfred Cort. 1894. The Decorative Art of British New Guinea. Dublin: Royal Irish Academy.

Heymer, Armin. 1977. Vocabulaire éthologique: Allemand - Anglais - Français. Berlin: Parey.

Jahoda, Gustav. 1995. In pursuit of the emic-etic distinction: Can we ever capture it? In Nancy Rule Goldberger \& Jody Bennett Veroff (eds.), The Culture and Psychology Reader, 128-138. New York: New York University Press.

Labov, William. 1972. Some principles of linguistic methodology. Language in Society 1. 97-120.

Leach, Jerry W. \& Leach, Edmund (eds). 1983. The Kula. New Perspectives on Massim Exchange. Cambridge: Cambridge University Press.

Liep, John. 2015. Dogomomo Xmas, Kwangwe's Races, and a Murder: W. E. Armstrong and the Rossel Island Money. Oceania 85: 183-198. doi: 10.1002/ocea.5079

Malinowski, Bronislaw. 1920. Classificatory particles in the language of Kiriwina. Bulletin of the School of Oriental Studies, London Institution, Vol. I, part IV. 33-78.

Malinowski, Bronislaw. 1922. Argonauts of the Western Pacific. London: Routledge \& Kegan Paul.

Malinowski, Bronislaw. 1923. The problem of meaning in primitive languages. In C. K. Ogden \& I. A. Richards. The Meaning of Meaning. A study of the Influence of language upon thought and of the science of symbolism. Supplement I. 296-336. London: Kegan Paul, Trench, Trubner. (Fourth edition revised 1936).

Malinowski, Bronislaw. 1929. The Sexual Life of Savages in North-Western Melanesia. New York: Harcourt, Brace \& World.

Malinowski, Bronislaw. 1935. Coral Gardens and their Magic. Vol. I: The Description of Gardening. Vol. II: The Language of Magic and Gardening. London: George Allen \& Unwin.

Passer, Matthias B. 2016. The Typology and Diachrony of Nominal Classification. University of Amsterdam PhD thesis. Utrecht: LOT.

Pheby, John \& Scholze, Werner (eds.). 1979. Oxford Duden Bildwörterbuch Deutsch und Englisch. Mannheim: Bibliographisches Institut.

Persson, Johnny. 1999. Sagali and the Kula. A Regional System Analysis of the Massim. [Lund Monographs in Social Anthropology 7]. Lund: Department of Sociology, Lund University.

Pike, Kenneth L. 1954. Language in Relation to a Unified Theory of the Structure of Human Behaviour. Part 1. Glendale: Summer Institute of Linguistics.

Powdermaker, Hortense. 1966. Stranger and Friend. The Way of an Anthropologist. New York: W. Norton.

Senft, Barbara \& Senft, Gunter. 2018. Growing Up on the Trobriand Islands in Papua New Guinea - Childhood and Educational Ideologies in Tauwema. Amsterdam: John Benjamins. [Downloadable under the following URL: https://doi.org/10.1075/clu.21]

Senft, Gunter. 1986. Kilivila: The Language of the Trobriand Islanders. Berlin: Mouton de Gruyter. doi: 10.1515/9783110861846

Senft, Gunter. 1987. Kilivila color terms. Studies in Language 11. 313-346. doi: 10.1075/s1.11..03sen 
Senft, Gunter. 1991. Mahnreden auf den Trobriand Inseln: Eine Fallstudie. In D. Flader (ed.), Verbale Interaktion: Studien zur Empirie und Methologie der Pragmatik, 27-49. Stuttgart: Metzler.

Senft, Gunter. 1994. These 'Procrustean' feelings: Some of my problems in describing Kilivila. Semaian 11.86-105.

Senft, Gunter. 1995. Notes from the field: Ain't misbehavin'? Trobriand pragmatics and the field researcher's opportunity to put his (or her) foot in it. Oceanic Linguistics 34. 211-226. doi: $10.2307 / 3623120$

Senft, Gunter. 1996. Classificatory Particles in Kilivila. New York: Oxford University Press.

Senft, Gunter (ed). 2000. Systems of Nominal Classification. Cambridge: Cambridge University Press.

Senft, Gunter. 2001. Frames of spatial reference in Kilivila. Studies in Language, 25: $521-$ 555. doi: $10.1075 / \mathrm{s} 1.25 .3 .05 \mathrm{sen}$

Senft, Gunter. 2006. A biography in the strict sense of the term [Review article of the book Malinowski: Odyssee of an anthropologist 1884-1920, Vol. 1 by Michael Young]. Journal of Pragmatics 38. 610 - 637. doi: 10.1016/j.pragma.2005.06.012

Senft, Gunter. 2008a. Zur Bedeutung der Sprache für die Feldforschung. In Bettina Beer (ed.), Methoden ethnologischer Feldforschung, 103-118. Berlin: Reimer.

Senft, Gunter (ed.). 2008b. Event conceptualization and event report in serial verb constructions in Kilivila: Towards a new approach to research and old phenomenon. In Gunter Senft (ed.), Serial Verb Constructions in Austronesian and Papuan Languages, 203-230. Canberra: Pacific Linguistics.

Senft, Gunter. 2009a. Bronislaw Kasper Malinowski. In Gunter Senft, Jan-Ola Östman \& Jef Verschueren (eds), Culture and Language Use, 210-225. Amsterdam: John Benjamins. doi: 10.1075/hoph.2.19sen

Senft, Gunter. 2009b. Trobriand Islanders' forms of ritual communication. In Gunter Senft \& Ellen B. Basso (eds.), Ritual Communication, 81-101. Oxford: Berg.

Senft, Gunter. 2010. The Trobriand Islanders' Ways of Speaking. Berlin: de Gruyter Mouton. doi:10.1515/9783110227994

Senft, Gunter. 2011. Talking about color and taste on the Trobriand Islands: A diachronic study. The Senses \& Society 6. 48 - 56. doi: 10.2752/174589311X12893982233713

Senft, Gunter. 2012a. Das Erlernen von Fremdsprachen als Voraussetzung für erfolgreiche Feldforschung. In Jan Kruse, Sthephanie Bethmann, Debora Niermann \& Christian Schmieder (eds.), Qualitative Interviewforschung in und mit fremden Sprachen: Eine Einführung in Theorie und Praxis, 121-135. Weinheim: Beltz Juventa.

Senft, Gunter. 2012b. Referring to colour and taste in Kilivila: Stability and change in two lexical domains of sensual perception. In Andrea. C. Schalley (ed.), Practical Theories and Empirical Practice, 71-98. Amsterdam: John Benjamins. doi: 10.1075/hcp.40.04sen

Senft, Gunter. 2014. Understanding Pragmatics. London: Routledge.

Senft, Gunter. 2017a. "Control your emotions! If teasing provokes you, you've lost your face.." The Trobriand Islanders' control of their public display of emotions. In Anne Storch (ed.), Consensus and Dissent: Negotiating Emotion in the Public Space, 59-80. Amsterdam: John Benjamins. doi: 10.1075/clu10.04sen

Senft, Gunter. 2017b. Expressions for emotions - and inner feelings - in Kilivila, the language of the Trobriand Islanders: A descriptive and methodological critical essay. In N. Tersis \& P. Boyeldieu (eds.), Le langage de l'emotion: Variations linguistiques et culturelles, 349-376. Paris: Peeters.

Senft, Gunter. 2018. Pragmatics and anthropology — The Trobriand Islanders' ways of speaking. In Cornelia Ilie \& Neal Norrick (eds.), Pragmatics and its Interfaces, 185-211. Amsterdam: John Benjamins. doi: https://doi.org/10.1075/pbns.294.09sen 
Sherzer, Joel. 1983. Kuna Ways of Speaking: An Ethnographic Perspective. Austin: University of Texas Press.

Werner, Oswald. 1994. Ethnography and Translation — Issues and Challenges. In Sartoniana 7. $59-135$

Young, Michael W. 2004. Malinowski: Odyssee of an Anthropologist 1884-1920, Vol. 1. New Haven: Yale University Press.

See also: https://www.mpi.nl/people/senft-gunter/publications

\section{Article history:}

Received: 10 August 2019

Revised: 18 October 2019

Accepted: 09 November 2019

\section{История статьи:}

Дата поступления в редакцию: 10 августа 2019

Дата принятия к печати: 09 ноября 2019

\section{Bionote:}

GUNTER SENFT is senior investigator at the Max Planck Institute for Psycholinguistics in Nijmegen (The Netherlands) and extraordinary professor of general linguistics at the University of Cologne (Germany). He has been studying the language and the culture of the Trobriand Islanders of Papua New Guinea since 1982 and conducted field research on the Trobriand Islands for 45 months during16 long- and short term field-trips between 1982 and 2012. Research interests: Austronesian and Papuan languages, anthropological linguistics, pragmatics, semantics, the interface between language, culture, and cognition, the conceptualization of space and spatial reference, serial verb constructions and systems of nominal classification. Among his publications figure more than 150 articles in journals, handbooks and anthologies and 22 books (including 8 monographs).

\section{Contact information:}

E-mail: Gunter.Senft@mpi.nl

Website: http://www.mpi.nl/people/senft-gunter

Publications: http://www.mpi.nl/people/senft-gunter/ publications

Address: PB 310, NL-6500 AH Nijmegen, The Netherlands

\section{Сведения об авторе:}

ГЮНТЕР СЕНФТ - старший научный сотрудник Института психолингвистики Макса Планка (Нидерланды), почетный профессор лингвистики Кельнского университета. С 1982 г. изучает языки и культуру жителей островов Тробриан (ПапуаНовая Гвинея), где провел в общей сложности около 4 лет, совершив 16 исследовательских поездок. Сфера научных интересов: австронезийские и папуасские языки, антропологическая лингвистика, прагматика, семантика, взаимодействие языка, культуры и сознания, концептуализация пространства и пространственных отношений. Список публикаций насчитывает более 150 статей и 22 книги (включая 8 монографий).

\section{Контактная информация:}

E-mail: Gunter.Senft@mpi.nl

Вебсайт: http://www.mpi.nl/people/senft-gunter;

Публикации: http://www.mpi.nl/people/senft-gunter/publications

Aдрес: PB 310, NL-6500 AH Nijmegen, The Netherlands 